\title{
Bacterial Oxidation of Pyrite Surface
}

\author{
S. Lipko ${ }^{1(\bowtie)}$, I. Lipko ${ }^{2}$, K. Arsent'ev ${ }^{2}$, and V. Tauson ${ }^{1}$ \\ ${ }^{1}$ Vinogradov Institute of Geochemistry SB RAS, Irkutsk, Russia \\ slipko@yandex.ru \\ ${ }^{2}$ Limnological Institute SB RAS, Irkutsk, Russia
}

\begin{abstract}
The article considers the study of the role of bacteria in the surface oxidation of pyrite. The experiment provided the data on characteristic morphological changes of the surface and the first data on influence of a nonautonomous phase (NP) on bacterial oxidation.
\end{abstract}

Keywords: Pyrite $\cdot$ Iron-oxidizing bacteria $\cdot$ SEM-EDAX $\cdot$

Non-autonomous phase $\cdot$ Surface

\section{Introduction}

For many years, extensive studies have been conducted on the processes of diagenetic redistribution of ore-forming components in the Earth's lithosphere and the formation of iron-containing nodules and ores, aimed at the their prospective industrial use. Most researchers believe that the earliest microbial ecosystems were based on sulfur transformations - sulfate-reduction and disproportionation (Wacey et al. 2011).

The choice of pyrite as the object of study is geochemically justified by the close connections of iron sulfides with organic matter in various environments, including hydrothermal conditions (Lindgren et al. 2011).

Although the chemistry of the processes has been studied in principle, there remains a number of unresolved issues. The most important are proof of paleobacterial processes and determination of their role in the formation of mineral deposits. Here the range of opinions is very wide: from complete denial to recognition of their leading character at the sedimentary-hydrothermal stage of ore formation (Vinichenko 2007). The morphological effects of the interaction of mineral surfaces with bacteria have not been sufficiently investigated, which complicates interpretation of natural observations. In particular, it is unclear what effect non-autonomous phases located within the surface layer of the crystal have on the interaction of bacterial communities with the pyrite surface (Tauson et al. 2008, 2009a). Non-autonomous phases (NP) are nanocrystalline objects formed in the surface layer of the crystal through interaction with its surface of the growth medium components or contacting autonomous (classical) phases. The experiment within the framework of present research used specially synthesized pyrite crystals with different degrees of NP development on the surface (Tauson and Lipko 2013), with the aim to study the process of interaction between bacteria and NP and to establish the role of surface phases in the oxidative processes initiated by the acidophilic iron bacteria. 


\section{Methods and Approaches}

The culture of acidophilic iron-oxidizing bacteria isolated from natural habitats (sulfide occurrences) of the Baikal area of the Irkutsk region was used for research on the biooxidation of the pyrite surface. This bacterial culture was provided by the laboratory № 7 of Irkutsk scientific-research Institute of rare and precious metals and diamonds, JSC "Irgiredmet". Iron-oxidizing bacteria are used in laboratory tests for bacterial oxidation of resistant iron-sulfide ores containing gold.

The synthesis of pyrite crystals was performed according to the standard technique of hydrothermal thermogradient synthesis in titanium inserts at $\mathrm{T}=450{ }^{\circ} \mathrm{C}$ and $500{ }^{\circ} \mathrm{C}$ and a pressure of $1 \mathrm{kbar}$ (Tauson et al. 2008). In the synthesis of pyrite $\mathrm{Fe}^{+} \mathrm{S}$ charge was used, the composition of the surface non-autonomous phase was regulated by the activity of sulfur depending on Fe/S ratio. The obtained crystals were up to $5 \mathrm{~mm}$ in size. Pyrite, obtained at high sulfur activity, contains virtually no NP on the surface. At lower sulfur activity, a layer of NP up to $\sim 500 \mathrm{~nm}$ thick with a base composition similar to pyrrhotite, but with different forms of sulfur, is formed: $\mathrm{Fe}^{2+}\left[\mathrm{S}, \mathrm{S}_{2}, \mathrm{Sn}\right]^{2-}$ (Tauson et al. 2008). These surface formations are able to absorb cationic impurities and oxysulfide anions.

To conduct research on pyrite bio-oxidation, a mixture of acidophilic iron bacteria was grown on a liquid $9 \mathrm{~K}$ medium at room temperature and constant stirring within 5 days. In eight $250 \mathrm{ml}$ conical flasks with $50 \mathrm{ml}$ of $9 \mathrm{~K}$ medium (without $\mathrm{FeSO}_{4}$ ) there were placed pieces of polished pyrite (4 flasks) and 5-6 pieces of pyrite with nonautonomous phases (4 flasks). The medium and pyrite flasks were sterilized at $0.5 \mathrm{~atm}$. for $10 \mathrm{~min}$ to minimize pyrite oxidation. After cooling the medium, 6 flasks were inoculated with 5-day bacterial culture. Previously, the culture was centrifuged and washed from the medium residues with iron in $0.01 \mathrm{~m} \mathrm{H}_{2} \mathrm{SO}_{4}$. The concentration of iron bacteria cells added to the medium with pyrite was about $1 * 10^{7}$ cells $/ \mathrm{ml}$. The remaining two flasks with polished pyrite and NP on the pyrite surface were used as a control, without bacteria. Cultivation took place at room temperature and constant stirring on a shaker (about 110 rotation/min) for three weeks. Every week 2 flasks with different samples of pyrite were selected for further research. The flasks with control samples were examined after 3 weeks of cultivation. The bacterial film from the pyrite samples were washed with $2 \%$ aqueous solution of Polysorbate Tween 80 . Pyrite crystals washed after the experiment were dried in air and analyzed on the scanning multi-microscope SMM 2000 in atomic force mode, scanning electron microscope FEI Quanta Company (USA) 200 with energy dispersive device EDAX for X-ray microanalysis.

\section{Results and Discussion}

The experiment on pyrite bio-oxidation established that the surface of polished pyrite is less susceptible to bacterial oxidation as compared with NP-containing pyrite. Microphotographs show the surfaces of polished pyrite (roughness less than $5 \mathrm{~nm}$ ) and NP-containing pyrite (roughness more than $300 \mathrm{~nm}$ ) after two weeks of bacterial cultivation (Fig. 1). 

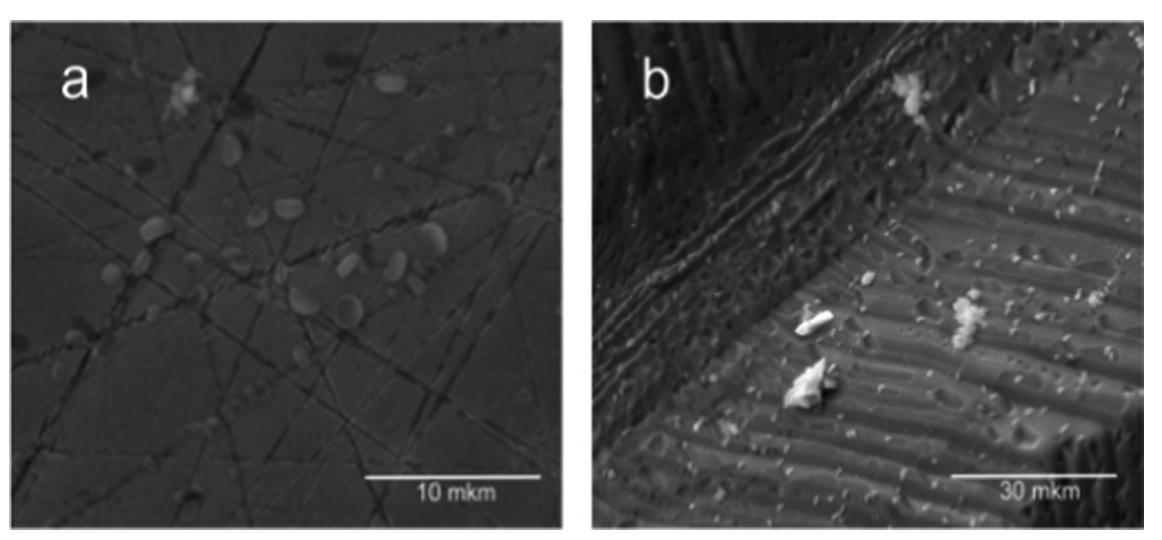

Fig. 1. Surface morphology of pyrite (scanning electron microscopy). a - polished surface, $\mathrm{b}-$ NP-containing surface.

The surface with NP exhibits bacteria and characteristic traces of interaction between bacteria and pyrite in the form of holes of different size comparable to the sizes of bacteria. For polished pyrite, these traces are almost absent and are observed only on the borders of scratches left from polishing. A similar result was obtained for the pyrite surface with minimal NP development synthesized at high sulfur activity. Therefore, the activity of bacteria is associated with the structure of pyrite surface. Similar formations, but significantly smaller (nano-holes) were discovered earlier, in the study of pyrites from the Sukhoi Log gold deposit (Irkutsk region) (Tauson et al. $2009 \mathrm{~b})$. This confirms the affinity of processes occurring in nature and in the experiment.

\section{Conclusions}

The research resulted in acquisition of data on pyrite bio-oxidation taking into account the structure of crystal surface under the given conditions. For this purpose, crystals with different degrees of non-autonomous phases development on the surface controlled by growth conditions were synthesized and used in the experiment for the first time. It was found that the surface of polished pyrite is less susceptible to bacterial oxidation, as compared with pyrite containing a non-autonomous phase. The resulting characteristic morphological changes in the surface will further be instrumental in addressing the issues of ore genesis, as well as identifying minerals that were formed at the initial or final stage of growth involving bacteria.

Acknowledgements. We thank Alexandra Mikhailova for suppling of bacterial culture. The research was performed within a state assignment, Project IX.125.3, No. 0350-2016-0025 and was funded by the Federal Agency for Scientific Organizations (FASO) within the framework of State Tasks No. 0345-2016-0003 (AAAAA16- 116122110061-6). 


\section{References}

Lindgren P, Parnell J, Holm NG, Broman C (2011) A demonstration of the affinity between pyrite and organic matter in a hydrothermal setting. J Geochem Trans 12(3):3-7

Tauson VL, Lipko SV (2013) Pyrite as a concentrator of gold in laboratory and natural systems: a surface-related effect. In: Whitley N, Vinsen PT (eds) Pyrite: Synthesis, Characterization and Uses Chapter 1. Nova Science Publisher Inc., New York, pp 1-40

Tauson VL, Babkin DN, Lustenberg EE, Lipko SV, Parkhomenko IY (2008) Surface typochemistry of hydrothermal pyrite: electron spectroscopic and scanning probe microscopic data I. Synthetic pyrite. J Geochem Int 46(6):615-628

Tauson VL, Kravtsova RG, Grebenshchikova VI, Lustenberg EE, Lipko SV (2009a) Surface typochemistry of hydrothermal pyrite: electron spectroscopic and scanning probe microscopic data II. Natural pyrite. J Geochem Int 47(3):245-258

Tauson VL, Lipko SV, Shchegolkov YuV (2009b) Surface nanoscale relief of mineral crystals and its relation to non-autonomous phase formation. J Crystallogr Rep 54(7):1219-1227

Vinichenko PV (2007) Biogeology and Ore Formation. Izd-e Sosnovgeologiya, Irkutsk

Wacey D, Saunders M, Brasier MD, Kilburn MR (2011) Earliest microbially mediated pyrite oxidation in 3.4 billion-year-old sediments. J Earth Planet Sci Lett 301:393-402

Open Access This chapter is licensed under the terms of the Creative Commons Attribution 4.0 International License (http://creativecommons.org/licenses/by/4.0/), which permits use, sharing, adaptation, distribution and reproduction in any medium or format, as long as you give appropriate credit to the original author(s) and the source, provide a link to the Creative Commons license and indicate if changes were made.

The images or other third party material in this chapter are included in the chapter's Creative Commons license, unless indicated otherwise in a credit line to the material. If material is not included in the chapter's Creative Commons license and your intended use is not permitted by statutory regulation or exceeds the permitted use, you will need to obtain permission directly from the copyright holder.

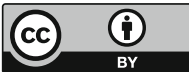

